\title{
O OLHAR, A PALAVRA E A AUDIODESCRIÇÃO (AD)
}

\author{
Admilson Santos* \\ Luciene Maria da Silva** \\ Sandra Regina Rosa Farias***
}

\section{RESUMO}

As pessoas com deficiência visual contam com um recurso de acessibilidade denominado Audiodescrição (AD) que consiste, grosso modo, na descrição de informações que são veiculadas visualmente em um filme, programa de televisão, peça de teatro, fotografia, pintura, escultura ou o que mais envolva imagem. O debate atual sobre AD perpassa por problematizar as questões estéticas na sua realização. Para pensar sobre essas fissuras das abordagens a respeito da recepção pelas pessoas cegas, recorremos ao filme documentário Janela da Alma, dos cineastas João Jardim e Walter Carvalho, de 2001, em diálogo com autores que refletiram sobre a proeminência do olhar. Em seguida abordamos e refletimos sobre o papel da palavra, com base em Bakhtin $(2003,2006)$ e outros autores. Realizada deste lugar, a AD será fruto da consciência de que somos pelo reconhecimento das nossas possibilidades e do outro, bem como pelo respeito à diversidade e às diferenças.

Palavras-chave: Audiodescrição. Palavra. Pessoa com deficiência visual.

\begin{abstract}
THE LOOK, THE WORD AND THE AUDIODESCRIPTION

Visually impaired people count on an accessibility resource denominated Audio Description (AD) which is roughly consisted of the description of information broadcasted in a movie, a TV program, theatrical play, photography, paintwork and everything else involving images. The current debate on AD encompasses problematizing aesthetical issues during its realization. In order to think about those chinks in the approaches on the way blind people receive it, we resort to the documentary Janela da Alma by filmmakers João Jardim and Walter Carvalho (2001), in a dialog with authors who reflected upon sight prominence. Next, we approach and reflect upon the role of the word itself, based on Bakhtin $(2003,2006)$ and other authors. Performed under that perspective, Audio Description will be stemming from the conscience that we are for the recognition of our capabilities and of the other's, as well as for showing respect for diversity and for difference.
\end{abstract}

Keywords: Audio Description; Word; Visually impaired people

* Doutor em Educação pela Universidade Federal da Bahia (UFBA). Professor Associado da Universidade Federal da Bahia (UFBA). Coordenador do Núcleo de Pesquisa e Extensão Educação Física e Esporte Adaptado da Universidade Estadual de Feira de Santana (NEFEA/UEFS). E-mail: admil@ufba.br

** Doutora em Educação pela Pontifícia Universidade Católica de São Paulo (PUC/SP). Professora Titular da Universidade do Estado da Bahia (UNEB) e do Programa de Pós-Graduação em Educação e Contemporaneidade (PPGEDUC/UNEB). E-mail: lucienemaria05@gmail.com

*** Doutora em Educação pela Universidade Federal da Bahia (UFBA). Professora Adjunta da Universidade do Estado da Bahia (UNEB). Coordenadora do Grupo de Pesquisa e Extensão Acessibilidade \& Arte (GA\&A/UNEB). Membro do grupo de Pesquisa Tradução, Mídia e Audiodescrição (TRAMAD/ UFBA). E-mail: srrosaf@gmail.com 


\section{RESUMEN}

\section{LA MIRADA, LA PALABRA Y LA AUDIODESCRIPCIÓN}

Las personas con deficiencia visual disponen de un recurso de accesibilidad llamado Audiodescripción (AD), que consiste, de manera general, en la descripción de informaciones que son transmitidas a través de imágenes en una película, en programas de televisión, obras de teatro, fotografías, pinturas, esculturas y etc. El debate actual sobre AD se centra en problematizar los aspectos estéticos en la puesta en práctica de la misma. Para reflexionar sobre las fisuras en los abordajes respecto a la recepción de las personas ciegas, recorremos al documental "Ventana del alma", de los cineastas João Jardim de Walter Carvalho (2001), en charla con autores que hicieron reflexiones sobre la preeminencia de la mirada. De seguido, abordamos y reflexionamos sobre el papel de la palabra, basándonos en Bakhtin $(2003,2006)$ y en otros autores. Realizada desde este lugar, la $\mathrm{AD}$ será fruto de la conciencia de somos por el reconocimiento de nuestras posibilidades y del otro, así como como por el respeto a la diversidad y a las diferencias.

Palabras clave: Audiodescripción. Palabra. Persona con deficiencia visual.

\section{Notas sobre sentidos da visão: olhar que aprisiona ou liberta?}

Em tempos de excesso e hipervalorização da imagem, em que signos condensados buscam expressar conceitos e sentimentos, e o olhar busca, forçadamente, capturar em tempo mínimo estímulos provenientes do ambiente social, somos instados a pensar sobre as possibilidades dos indivíduos que têm limitações sensório-visuais para aquisição de conhecimentos e informações. A visão é um sentido que suscita muitas representações sobre como indivíduos que nunca enxergaram ou se tornaram cegos apreendem o mundo. Muitos ainda creditam reduzidas possibilidades cognitivas à pessoa cega, resultando em baixa expectativa quanto ao seu aprendizado, reiterando crenças e atitudes historicamente difundidas, que se mantêm vivas alimentando preconceitos e estigmas. Contudo, a percepção do mundo transcende a experiência dos sentidos, buscando, de forma dinâmica, a mais adequada interpretação do que lhe é apresentado (ORMELEZI, 2006). Tal percepção ocorre, principalmente, por meio das experiências pessoais, a partir de um estar no mundo que se faz com o corpo sensível e com a cultura. Nesse sentido, a pergunta implícita não pode partir da negação da visão, mas das condições, mecanismos e ferramentas que alimentam a percepção. Assim pensando, neutralizamos as dicotomias em torno do ser visual, retirando a ênfase na eficiência do que falta, privilegiando possibilidades e potências.

O documentário Janela da Alma (2001), dirigido por João Jardim e Walter Carvalho, parece um bom ponto de partida para um exercício de reflexão sobre o sentido da visão. Pode ser que a imagem inicial do fogo seja para contrapor ou tensionar o sentido visual e a sensação térmica ardente, problematizando a imagem sólida e a visão como essência da experiência. O documentário mostra evidências e suposições de pessoas, algumas conhecidas personalidades, sobre suas percepções visuais, suas relações com o sentido da visão. Cegos ou com baixa visão, míopes e estrábicos nos falam como convivem com a canônica cultura visual e, dessa forma, põem em cena compreensões sobre o olhar, não o reduzindo puramente à visão, mas ao que ela possibilita nas interações com outras percepções e sentidos: o olhar do outro, a visão fora de foco, o enquadramento e a subjetividade do olhar são abordagens constantes. Esses sujeitos expressam o interesse pelo sentido da visão como uma forma de olhar que ultrapassa a função de enxergar. Necessário salientar as imagens desfocadas da cena urbana noturna imprimindo uma beleza poética na distorção, fugindo da obviedade perturbadora que causa a ausência da visão biológica. 
As abordagens e a bela fotografia do documentário são interessantes para destacar a questão da objetividade ainda enfatizada como fundamental por muitos realizadores da Audiodescrição (AD). Como se tivéssemos uma única forma de olhar (e apreender) o mundo e, a partir deste princípio, descrevê-lo. Discordando desta visão, de objetividade enquanto contrária à expressividade, poética, poesia, subjetividade, Farias (2013) diz que é uma visão pautada nos princípios da ciência institucionalmente organizada como produção da verdade, valorada no positivismo, que visa um resultado acabado, perfeito. De acordo com Furtado (1999, p. 126), baseado "tanto na evidência quanto na universalidade da ordem mecânica da natureza e da sociedade quanto na naturalidade do cultural", esta proposição é herdada de ciências apoiadas em culturas colonizadoras pensadas de acordo com um ideal político. Farias (2013), sobre este lugar, ainda nos diz que descrever as imagens desta forma, tal como elas se apresentam (se isso for possível), seria atender à objetividade em conformidade para atestar os interesses de uma determinada forma histórica de conhecimento.

Esse direcionamento para a $\mathrm{AD}$, de alguma forma, tem a mesma fundamentação da criticada pelos entrevistados em Janela da Alma (JANELA..., 2001), já que dá um lugar de predomínio à visão, que precisa ser realizada tanto no olhar para o mundo (as imagens) quanto na tradução (as palavras), de forma a ser representada de maneira idêntica, ou seja, como se houvesse a possibilidade dessa total correspondência entre imagem e sua tradução. É o entendimento que afirma não ser possível outra forma de apreensão do mundo pelas pessoas com deficiência, que não pela via da objetividade/neutralidade, inclusive as produções em AD.

Podemos identificar dentre as compreensões dos entrevistados algumas menções críticas sugestivas desta pseudopreponderância da visão, a exemplo do escritor Oliver Sacks, que diz ser o ato de ver não apenas o olhar para fora, mas também para o invisível, tornando possível a imaginação: "Todos nós somos criaturas emocionais, e creio que todas as percepções, as nossas sensações e experiências são carregadas de emoção pessoal. Acredito que a emoção fique, por assim dizer, codificada na imagem. Às vezes, a emoção pode separar-se da imagem" (JANELA..., 2001). O poeta Manoel de Barros, de forma semelhante, fala que o olho vê, a lembrança revê as coisas, mas é a imaginação e a fantasia que transfiguram o mundo, indicando, assim, que o visto nem sempre é o que fica apreendido, mas o que dele deriva. Então, releva registrar que é no âmbito das relações sociais, pela história e pela cultura, que os significados das coisas do mundo se constituem. A compreensão não é algo que se faz automaticamente, posto que as experiências são fundamentais como mediação para a constituição do indivíduo, o que permite a diferenciação (JANELA..., 2001).

A cultura contemporânea nos convoca a olhar obstinadamente para imagens produzidas, muitas vezes imagens desnorteadoras do pensamento, sem objeto, porque sem um sujeito do conhecimento (MATOS, 2010). Nesse sentido, parece que a imagem vem gradualmente substituindo a coisa/objeto da qual ela é apenas imagem. Seu excesso resulta no efeito contrário, que é a banalização do olhar; já não temos o tempo de magia para decifrar a cena, conforme nos alerta Flusser (1983). A idolatria visual impõe um ritmo frenético para a absorção das imagens, impedindo o foco nos detalhes, já não tão sutis, posto que desvelados. Pensemos na ansiedade inquieta do turista que a tudo quer fotografar, tão rapidamente quanto seja possível, para poder mostrar que conhece os "paraísos turísticos" pasteurizados, visitados impessoalmente e sem contemplação.

Embora a visão permita revisitar o objeto mirado, estamos nos tornando cada vez mais incapacitados para a percepção dos detalhes sutis, considerando a fugacidade da imagem que atualmente cria-se a si própria, passando a nada significar além do momento de captura como mercadoria; banaliza-se, perdendo a possibilidade de emocionar. Ao mesmo tempo em que observamos uma inflação de possibilidades de significados dados pela imagem, não conseguimos reconhecê-los devido à saturação extrema e ao empobrecimento da experiência que limitam os repertórios linguísticos e a elaboração do pensamento. Pode ser este o sentido que Evgen Bavcar busca evidenciar quando afirma que vivemos em meio a tantos clichês que não necessitamos da imagem para entender as mensagens (JANELA..., 2001). 
O olhar como o sentido da ordem ou modelo de captação do saber é impelido como perspectiva por Wim Wenders, quando afirma que "[...] felizmente a maioria de nós é capaz de ver com os ouvidos, de ouvir e ver com o cérebro, o estômago e a alma. Creio que vemos em parte com os olhos, mas não exclusivamente" (JANELA..., 2001). Isso contraria a visão cientificista que identifica conhecimento e saber com a visão ou clarividência.

Nessa perspectiva, os seres humanos, de acordo com Elias (1994), podem ter uma visão do mundo de duas formas diferentes: um mundo que pode ser representado muito claramente através de símbolos de assiduidade imutáveis e um mundo que representa a estrutura de mudança sequencial. $\mathrm{O}$ primeiro está diretamente ligado à natureza e o segundo à história ou cultura. Na teoria sociológica eliasiana, a concepção totalizadora e individualista não é aceita; ao contrário, os indivíduos, a partir de suas necessidades, são orientados uns para os outros, sempre unidos uns aos outros, formando, assim, uma assiduidade imutável e uma mudança sequencial através da história e da cultura.

De fato, o que vemos em um determinado lugar, espaço, com suas formas e cores variadas, é também simulação visual, onde o indivíduo vê de acordo com a sua realidade, sua profissão, sua história de vida, e sua cultura, pois os espaços escondem e realçam os vários seres através de suas alterações espaço-temporais e suas representações. Estas representações fazem parte da dimensão da percepção que, na verdade, é um processo seletivo, a princípio do olhar, não um conhecimento, pois vai depender da interpretação individual, de um estado de espírito, um corpo de costumes e tradições (SANTOS, 2004).

De onde vem essa ideia, a de que o olhar é o primeiro sentido a ser intimado à ordem? Seria "[...] em virtude do prestígio que a visão passou a ter em nossa cultura, concentrando em si a inteligência e as paixões?" (NOVAES, 1988, p. 9). Ora, as descrenças e dúvidas foram marcas intelectuais no período do Renascimento, que fizeram surgir, ou reforçaram, concepções diversas sobre a natureza do conhecimento e da verdade. A perspectiva empirista considerou que as ideias são provenientes das percepções sensoriais, o que significa que nada viria à mente sem ter passado pela experiência.
Outras concepções advogaram a razão como uma faculdade subjetiva da mente. Nesse sentido, indaga Chauí (1998, p. 44): "Por que espantarmos, afinal, com o privilégio do olhar? Não tem sido a história da filosofia o interminável debate entre o ser e o aparecer, o aparecer e o parecer, o parecer e o ser? Não é a teoria do conhecimento a longa 'Dialética do Esclarecimento'?” Essa herança é o que preconiza a soberania do olhar fisiológico como condição de conhecimento. Não é sem razão que usamos tantas expressões cotidianas como para atribuir um poder natural ou excepcional ao olhar, algo como uma fé perceptiva: falamos "à primeira vista", visionário, evidência, "visão de mundo", "mau olhado", revisionista, entre outras significações (CHAUÍ, 1988).

O modo como socialmente se apreende a experiência da cegueira advém também da percepção que se tem sobre deficiência. Inscreve-se aí uma leitura que se configura a partir de arranjos sociais. A deficiência como variação do normal surge com a necessidade de controle social e vigilância no final do século XVIII e ao longo do século XIX. Como afirma Martins (2006, p. 106), é uma abordagem que "nasceu alojada nas próprias estruturas culturais, sociais e econômicas em que assentam as sociedades modernas". Por essa abordagem, que emerge da biomedicina, ser deficiente é estar fora da norma, entendida como um conjunto de traços definidores de um modelo que expressa o distanciamento entre os indivíduos. Sendo o indivíduo um anormal, a deficiência torna-se um problema dele, forçando-o a uma adaptação ou necessidade de correção daquilo que provoca rejeição. Sobre isso, diz Von Der Weid (2014, p. 50): "a coisa certa a ser feita seria o princípio bastante direto de intervir e reparar o déficit, para que a pessoa deficiente se torne física ou mentalmente competente, o mais próximo possível de uma pessoa normal”. Assim, constitui-se uma ideologia sobre o indivíduo mais utilizável para fins rentáveis, ficando fora desse contexto as pessoas com deficiência, em razão de sua suposta inadequação à sociedade, merecedoras, portanto, da benevolência em razão da condição de dependência necessária.

Nesse contexto, forjam-se representações das pessoas com deficiência como indivíduos desafortunados e a cegueira, em especial, como expres- 
são de tragédia e infortúnio. A essa percepção se contrapõe o escritor Jorge Luis Borges, nas várias referências literárias à sua própria cegueira como uma condição não necessariamente de desventura: "a cegueira é uma clausura, mas é também uma libertação, uma solidão propícia às invenções, uma chave e uma álgebra" (BORGES, 1999, p. 90). Diz também: "o mundo do cego não é a noite que as pessoas supõem [...] não deve ser vista de modo patético. Deve ser vista como um modo de vida: é um dos estilos de vida dos homens" (BORGES, 1999, p. 317). Diniz (2007) deu ênfase à deficiência como estilo de vida ou mais uma forma de estar no mundo, tal como concebida por Borges. A abordagem social da deficiência, discutida pela antropóloga, compreende que as experiências são individuais e dependem dos contextos em que se realizam. Tira a deficiência do foco, pois deixa de considerar apenas os aspectos de lesão, perdas ou alterações orgânicas, tendo em conta também os aspectos sociais que a tornam um fenômeno de subalternidade. No caso da cegueira, neutraliza a sua predominância, alargando as possibilidades de recepção e desnaturalizando o predomínio do visual.

Na compreensão da deficiência como uma expressão da diversidade humana, a diferenciação e individuação ainda são promessas que nos desafiam, pois o indivíduo que se diferencia é um outro negado socialmente, em razão de uma base valorativa, estética e funcional que padroniza o olhar (SILVA, 2008). Cabe aqui uma breve lembrança do conto “Amor" de Clarice Lispector (1983, p. 23), no qual a personagem Ana, dona de casa contida no seu mundo limitado, se desestrutura emocionalmente no dia em que vê um cego mascando chiclete, desacompanhado no ponto de ônibus: “[...] olhava o cego profundamente, como se olha o que não nos vê. Ele mascava goma na escuridão. Sem sofrimento, com os olhos abertos". Talvez o homem tenha escapado do mundo previsível idealizado por Ana, com as coisas nos seus lugares binários e onde cegos são incapazes de perceber o que há em volta de si.

Esse entendimento ainda é compartilhado por uma grande parte da população. Por outro lado, nossa proposta é justamente pensar nas capacidades das pessoas com deficiência visual. E, neste caso, a capacidade delas de apreenderem o mundo com ampla intensidade, ou seja, pelas palavras. Assim, questionamos: por que a $\mathrm{AD}$ precisa ser objetiva e neutra se ela é composta de palavras e palavras fazem parte de grande parte da construção do mundo ${ }^{1}$ das pessoas com deficiência visual? Sendo as palavras esta obliquidade construtora de vida, as pessoas com deficiência visual nunca as vivenciaram pelo viés apenas neutro e objetivo. Por que com as palavras da $\mathrm{AD}$ precisa ser de tal modo? E nos perguntamos: o que é a palavra, então? Quais as suas possibilidades?

\section{Palavra: vivência ideológica}

E assim continuamos, até que de repente percebo: minhas palavras não têm música. Estou soprando em flauta rachada. O não-nascido não se explica, não se entende: se sente, se apalpa quando se move. E então deixo de explicar, e conto. (GALEANO, 1994, p. 09).

Simploriamente poderíamos dizer que palavra é um apanhado de letras que, unidas, a partir do padrão reconhecedor de um grupo, nomeia objetos, pessoas, a natureza, tudo. O que permite reconhecê-los. Nesse sentido, pode ser entendida como um artefato cultural, objeto do acordo de um grupo, podendo ser considerada certa, apropriada, exata, errada, inconveniente, censurável, injusta e tudo mais.

Segundo o Dicionário Aurélio (BUARQUE DE HOLANDA, 2004), palavra, do grego parabolé, enquanto substantivo feminino ou interjeição, pode ter diversos significados de acordo com o desígnio ao qual é proposta. De acordo com este dicionário, palavra pode ser uma "Unidade mínima com som e significado que pode, sozinha, constituir enunciado; forma livre [...]" (BUARQUE DE HOLANDA, 2004). Pode ser a "Alta expressão do pensamento; verbo [...]” (BUARQUE DE HOLANDA, 2004). Ou ainda a "Faculdade de expressar ideias por meio de sons articulados; fala [...]" (BUARQUE DE HOLANDA, 2004). Também expressa o "Modo de ver; opinião, afirmação, asserto [...] Alocução, oração, discurso [...] Doutrina [...]" (BUARQUE DE HOLANDA, 2004). Enquanto um conjunto de letras, podemos nos referir à palavra como um

1 Mundo que também se compõe por cheiros, texturas, paladar, propriocepção, entre outros 
fundamento gráfico da linguagem escrita; enquanto um apanhado de sons, podemos entendê-la como fundamento sonoro, da linguagem falada. Nos dois casos, se estabelece pela representação material da palavra, nominada vocábulo. E o índice da ideia que representa (sentido por trás da palavra escrita ou falada), que se refere à representação imaterial da palavra, nominada termo.

Historicamente, desde o homem primitivo, os aborígenes, passando pelos antigos egípcios e em várias larguezas da terra, Américas, África e mais, o fenômeno do poder da palavra está presente. Frazer (1956) menciona o poder da palavra relacionado à necessidade de segredo do nome de um grande chefe, de uma pessoa sagrada, de um rei, já que a palavra (nome) representa, é o ser a que ela se refere. Traz consigo sua essência, sua mais profunda unidade $e$, para não sofrer feitiços, mandingas, sortilégios, o mantinha em sigilo, não o revelava.

Em muitas tradições culturais, religiosas, míticas, a linguagem nasce com a palavra instituidora, que dá à humanidade a condição para ela se revelar. Segundo Gusdorf (1952 apud CRIPPA, 1975, p. 16), "Todas as grandes religiões conferem um lugar à doutrina do Verbo divino, na instituição do real". Assim Deus disse... e as coisas foram feitas. A partir destas tradições culturais, a existência e as coisas são em função do poder instituidor da palavra dita. No livro do Gênesis [I, 3-5], "Deus disse: 'Que a luz seja!' E a luz se fez. Deus viu que a luz era boa, e Deus separou a luz das trevas. Deus chamou à luz dia e às trevas noite" (BÍBLIA, 1995, p. 14). E assim se instituiu o primeiro dia. E assim se remetem significados de positivo, de bondade, de iluminado à luz, ao dia. E significados negativos de maldade, de trevas, à noite. Além do poder instituidor, a palavra também tem o poder vital, divino.

No princípio era a Palavra, e a Palavra estava com Deus, e a Palavra era Deus. Ela estava no início voltado para Deus. Tudo se fez por meio Dele; e sem Ele nada se fez do que foi feito. Nele estava a vida, e a vida era a luz dos homens, e a luz brilha nas trevas, e as trevas não a compreenderam. [...] E a Palavra se fez carne e habitou entre nós. (João, I, 1-5, 14). (BÍBLIA, 1995, p. 1353).

Hoje em dia nem tanto, mas ainda ouvimos e, por vezes, falamos provérbios para conferir este poder à palavra, algo como inerente à vida. E aqui trazemos alguns exemplos: "Para bom entendedor, meia palavra basta"; "Uma vez solta uma palavra, já não pode alcançá-la nem um cavalo a galope"; "Toda a palavra se deixa dizer"; "Toda a palavra é perdida se da alma não foi ouvida"; "As palavras não proferidas são flores do silêncio"; "Não há má palavra se a puserem no seu lugar", entre outros que poderiam ser citados.

A partir desses pressupostos, a palavra revela-se como o grande mote mobilizador da linguagem humana, já que, compreendendo seus códigos, estabelece interação, comunicação, podendo ser entendida inclusive como predominante à imagem, à visão. Entretanto, mesmo deste lugar de força, de poder, muitos são os significados e pressupostos teóricos que pautam a palavra. Vamos tentar trazer aqui algumas perspectivas para entendê-la e, então, pensá-la na $\mathrm{AD}$. A palavra pode ser entendida tanto pela dimensão cognitiva quanto pela socioambiental. Versaremos aqui sobre algumas possibilidades de pensá-la pelo viés socioambiental, que provê significações de poder representativo, interventor da palavra, o qual enuncia o entendimento da perspectiva aqui apontada para a realização da $\mathrm{AD}$, quer seja transcriar em palavras, quer em imagens.

É da interação do ser humano com o ambiente, para que a natureza atenda às suas necessidades, que a palavra se estabelece enquanto linguagem verbal, veículo de comunicação social, que cria significações e acompanha historicamente as transformações da sociedade. Segundo Vygotsky (2001, p. 11), o significado da palavra é uma unidade de duas funções da linguagem: a comunicação e o pensamento.

O significado das palavras só é um fenômeno de pensamento na medida em que é encarnado pela fala e só é um fenômeno linguístico na medida em que se encontra ligado com o pensamento e por este é iluminado. É um fenômeno do pensamento verbal ou da fala significante - uma união do pensamento e da linguagem.

Nesse sentido, é na vivência cotidiana, desde o nascimento, que a formação dos processos mentais se dá e fomenta uma extensa cadeia de conexões complexas que, pela vinculação da comunicação e do pensamento, a linguagem se dispõe como um 
meio de compreensão do mundo e, então, de enunciação do mesmo. Bakhtin (2002, p. 3) considera que este processo de formação advém de intervenções ideológicas que, enquanto signo "[...] não é apenas um reflexo, uma sombra da realidade, mas também um fragmento material dessa realidade". O que significa dizer que a palavra " $[\ldots .$.$] está sem-$ pre carregada de um conteúdo ou de um sentido ideológico vivencial" (BAKHTIN, 2006, p. 95). De tal modo, a palavra (bem como o discurso) está carregada de conteúdo ideológico, pois existe no mundo do real, nas enunciações sensíveis aos sujeitos.

Segundo Bakhtin (2002, p. 33), a "ideologia é um fato de consciência”. Assim sendo, os signos só se realizam a partir de um processo construído, de contínua interação de um sujeito com o outro, por meio das relações sociais. São processos que se efetivam entre verbalizações, ditos e não-ditos, avanços e retrocessos, constituições de significação que se darão por meio da interação verbal, fundadas pelo signo lingUístico, insurgidas desta consciência. Deste lugar, de acordo com Bakhtin (2002, P. 36), “[...] A palavra é o fenômeno ideológico por excelência. A realidade toda da palavra é absorvida por sua função de signo. [...] A palavra é o modo mais puro e sensível de relação social". Assim, a língua (palavra) empregada socialmente tem influência na maneira pela qual a sociedade concebe, interpreta e reage ao que é/ está posto, à realidade. De tal modo, as pessoas, ao se depararem com palavras (a partir da língua empregada), inicialmente não sabem o que elas farão consigo. Até têm expectativas, que só serão evocadas pelos significados que têm delas ou pelas indagações que poderão fazer ao não saber, a caminhar por terrenos de si mesmo, de outros e do mundo. Segundo Bakhtin (2006, p. 113), “A palavra é ponte lançada entre mim e os outros".

Desse modo, tomamos como propulsora a seguinte questão: o que a palavra tem a dizer do que o olhar vê? Como a palavra pode expressar o que o olhar vê?

Segundo o Dicionário Aurélio (BUARQUE DE HOLANDA, 2004), descrever, do latim describere, é um verbo transitivo direto que significa: 1 . Fazer a descrição de; narrar. 2. Expor, contar minuciosamente. 3. Fazer, perfazer, produzir, movimentando- -se; traçar. O ato de descrever, necessariamente, se dá apoiado na língua socialmente empregada, reconhecida. Entretanto, entender que descrever pode ser um ato neutro, talvez seja a expressão explícita da falta de conhecimento, dos muitos grupos, de que a pessoa que vai receber as palavras deste ato não seja capaz de compreender de forma expressiva, poética, subjetiva. Talvez, também, pelo desentendimento de que o ser humano, na sua diversidade, é capaz de muito, quase tudo; basta lhe disponibilizar o conhecimento, nas suas mais diversas formas de produção, e permiti-lo, no seu tempo, com a sua história, apropriar-se do que é do interesse de cada um.

Descrever dessa maneira, não ingenuamente, é uma relação social fundada em relações de poder, as quais privam o outro das muitas possibilidades educativas, sensíveis, cidadãs, históricas. Segundo Bakhtin (2002), é possível compreender a palavra como "signo neutro", todavia, isso não significa sem "carga ideológica". Enquanto signo, aufere responsabilidade significativa no processo de seu uso, já que faz parte de um amplo leque arraigado da língua. A palavra sozinha não tem um significado próprio, não tem "um tom emocional", ela está ligada a um conjunto enunciado. De acordo com o autor, "o significado neutro da palavra referida a uma determinada realidade concreta em determinadas condições reais de comunicação discursiva gera a centelha da expressão" (BAKHTIN, 2002, p. 292). Quando elaboramos o discurso, a enunciação está presente na sua forma esquemática (gênero) e no próprio projeto individual do sujeito do discurso. "Não enfiamos as palavras, não vamos de uma palavra a outra, mas é como se completássemos com as devidas palavras a totalidade" (BAKHTIN, 2002, p. 291-292) do discurso, impresso de expressão, já que "não são palavras o que pronunciamos ou escutamos, mas verdades ou mentiras, coisas boas ou más, importantes ou triviais, agradáveis ou desagradáveis etc.” (BAKHTIN, 2002, p. 95).

Em presença do que Bakhtin nos traz, não é um enunciado neutro então o que tem sido proposto para a AD, mas, ao fim, um enunciado pouco expressivo, desprovido de sensibilidade, esteticamente carente de reflexão. Ao aspirar pessoas críticas, criativas, construtoras de sua história coletiva e individual, outro olhar precisa ser lançado, numa 
perspectiva de um processo formativo, educativo, de autonomia, em que todas (as pessoas) possam atuar reflexivamente.

Nessa perspectiva, tanto para o olhar quanto para as palavras, é preciso conhecer. E, para conhecer, é preciso burilá-los, olhar e palavras, de todas as formas possíveis ou, como diz Saramago, no filme Janela da Alma, "para conhecer a coisa, há que dares a volta. Dares a volta na coisa toda" (JANELA..., 2001), tanto no uso pessoal quanto no descrever para o outro, para que, ao se juntarem (olhar e descrição), seja possível apresentar às pessoas audiodescrições que as permitam, as mobilizem, as deixem fruir. Tal como nos diz Wim Wenders, também no filme Janela da Alma, com relação aos livros:

O que mais me agradava nos livros era o fato de que aquilo que eles nos davam não se achava apenas dentro deles. Mas o que nós crianças adicionávamos a eles é que fazia a história acontecer. Quando criança, podíamos realmente ler entre as linhas e acrescentar-lhes toda a nossa imaginação. Nossa imaginação realmente complementa as palavras. (JANELA..., 2001).

Nesse sentido, propor textos (descrições) que requerem o envolvimento e a participação do outro num movimento dialógico/ideológico. $\mathrm{O}$ outro (espectador) é convidado a preencher os lugares vagos do texto e a transformar sua percepção sobre si mesmo e sobre o mundo. Segundo Umberto Eco, um texto solicita a colaboração do leitor, requer que este tente uma série de alternativas interpretativas "[...] que, se não infinitas, são ao menos indefinidas, e, em todo o caso, são mais que uma. [...]". Neste caso, o leitor, com o princípio ativo da interpretação, "constitui parte do quadro gerativo do próprio texto" (ECO, 1983, p. XI). De outro lugar (mas do mesmo), Oliver Sacks, no filme Janela da Alma, nos diz:

O ato de ver e olhar para fora não se limita a olhar o visível, mas também o invisível. De certa forma, é o que chamamos de imaginação. Se dizemos que os olhos são a janela da alma... sugerimos, de certa forma, que os olhos são passivos... e que as coisas apenas entram. Mas a alma e a imaginação também saem. O que vemos é constantemente modificado por nosso conhecimento... nossos anseios, nossos desejos, nossas emoções... pela cultura, pelas teorias científicas mais recentes [...]. Todos nós somos criaturas emocionais, e creio que todas as percepções, as nossas sensações e experiências são carregadas de emoção pessoal. Acredito que a emoção fique, por assim dizer, codificada na imagem. Às vezes, a emoção pode separar-se da imagem. (JANELA..., 2001).

Independentemente do lugar (sentido) pelo qual recebemos o conhecimento, este somente se completará com a nossa interferência, com o nosso olhar interno. Como podemos perceber, muitas são as possibilidades do olhar, desta janela (temos outras) que capta o mundo. Entretanto, na audiodescrição, esse olhar necessariamente é deslocado quando transformado em palavras. Como podemos então reconstruir esse olhar? Busca-se uma eficiência do olhar na palavra? Como ressignificar esse olhar com a palavra?

\section{Audiodescrição: palavra do olhar}

Que modo de ver é o modo como te vejo? [E audiodescrevo?] Pessoa (2006, p. 473).

No percurso de sua história, a $A D$ vem sendo concebida da perspectiva de diferentes olhares. À procura da própria especificidade e autonomia, já buscou saber se era importante sua existência; a exemplo, os estudos de Kuhn (1992 apud SCHMEIDLER; KIRCHNER, 2001) buscaram determinar se o seu uso contribuiria para que o público com deficiência visual compreendesse com mais facilidade materiais audiovisuais. Packer e Kirchner (1997), em sua pesquisa, reforçaram a importância da audiodescrição, apontando benefícios e o desejo do público de ter mais programas de televisão e vídeo com audiodescrição. No Brasil, Silva (2009), em sua pesquisa de mestrado, teve como objetivo delinear os primeiros parâmetros que pudessem contribuir para a construção de um modelo de audiodescrição que atendesse às características da criança brasileira não vidente. No Brasil, a AD procurou um termo para ser representada a partir da sua grafia (audiodescrição; áudio-descrição; áudio descrição), segundo Marinheiro (2010), pautado tanto no Acordo Ortográfico de 1990, como no Acordo Ortográfico de 1945, que, de acordo com ele, ainda vigora em Portugal: "o elemento áudio não é hifenizado (nem acentuado graficamente) 
quando é o primeiro elemento de compostos. Assim, a grafia da palavra é audiodescrição".

Audiodescritores e pesquisadores, já vislumbraram a $\mathrm{AD}$ neutra, clara e objetiva. $\mathrm{A} A \mathrm{AD}$ também foi/é entendida como não interpretativa, bem como ser objetiva significaria ser antônimo de expressiva e poética. Foi vista como recurso de acessibilidade; entre outros. Está claro que algumas dessas perpectivas não se sustentaram; outras se afirmaram e, por vezes, juntam-se a uma e/ou outra, dependendo do lugar de quem fala e do objetivo que se encerra sobre a mesma. Todavia, uma definição hoje é consenso: a AD é uma forma de tradução. Considerá-la, por este viés a tira do lugar de ser realizada apenas numa perspectiva (objetiva e neutra) e para um grupo de pessoas. Dependendo do produto/objetivo, a $\mathrm{AD}$ pode, sim, ser neutra, como vimos em Bakhtin anteriormente, mas este não é o seu único lugar. O que precisa ser levado em consideração, primordialmente, são os perfis diferenciados de pessoas com deficiência visual, em razão de propiciar-lhes o acesso ao conhecimento posto na imagem. Contudo, como tradução, a $\mathrm{AD}$ não pode meramente ser uma troca neutra de signos. Imagens não são simplesmente cambiadas por palavras.

Não pretendemos encerrar aqui um conceito, já que a audiodescrição é uma nascente, e ainda há um fértil caminho a ser percorrido para que seja entendida e definida (se é que isso é preciso). Todavia, um olhar é lançado sobre ela e, assim, do percurso vivenciado se coloca: A audiodescrição é uma transcriação (CAMPOS, 1992) autoral, artística, na qual, no seu processo, traz à luz, por meio das palavras, ${ }^{2}$ a representação de uma imagem. Em se tratando de arte, a AD cria outra arte pelas palavras. Expressiva, cria narrativas, poéticas, tessituras, poesias, prosas, discursos, reflexões.

Ou seja, produzir um estado poético com as palavras, de forma que uma implicação improvável, questionadora, opere ao mesmo tempo no intelecto, na memória, na sensibilidade, provocando intensidades inusitadas nas percepções da vida. Partir de uma língua que pode alienar para uma que tem um poder infinito de combinações,

2 Num processo de criação e provocação da representação se pode colocar cheiros, texturas, alimentos, entre outros que sensibilizem os sentidos para a imaginação e apropriação da obra. fonte inesgotável de cenários mesmo por nascer. Segundo Badiou (2002, p. 37), propor "uma poética fundadora [...] [em que] extraem-se novos métodos do pensamento poético, uma nova percepção dos recursos da língua, e não apenas do deleite de um brilho de presença".

Pensar a AD dessa forma significa entendê-la pela complexidade da teia discursiva que constitui os sujeitos situados nessa relação (autor da obra, audiodescritor e espectador), envolvidos num contexto social e cultural marcado pela imagem/ palavra, objetos da comunicação. Apoiando-se em Bakhtin, entendemos a AD também como um "fenômeno que funciona como signo ideológico e tem uma encarnação material, seja como som, como massa física, como cor, como movimento do corpo ou como outra coisa qualquer" (BAKHTIN, 2002, p. 33-34). Neste caso, a imagem se materializa na palavra, mas também no outro que a recebe (audiodescritor e espectador).

Considerando que a imagem é um texto, a transcriação pode servir para apontar o original, mas ela é um novo texto, crítico, criativo, autoral, que abarca uma nova "informação estética" (BENSE, 1971). Assim, a audiodescrição, em sua última forma, não precisa mais da imagem para ser. É com as palavras dispostas de forma reflexiva, poética, expressiva, sensível que ela vai existir. É com sua estética "nova" (já que expressar pela palavra não é novo, mas fazê-lo a partir da imagem pode ser considerado) que uma recente produção estética necessita ser criada, pensada.

Talvez seja um momento para a AD, apoiado em Deleuze e Guattari, da desterritorialização. Segundo estes autores (DELEUZE; GUATTARI 1992 apud MAYER, 2012), pensar é desterritorializar; todavia, o pensamento tão-somente se completa na criação e, para criar o "novo", é preciso romper com o território dado. É um movimento de linha de fuga que ascende uma reterritorialização. De acordo com Mayer (2012, p. 38), "um novo regime de enunciação, novos encontros, novas funções, novas identidades e compartilhamentos simbólicos". Para a AD, deixar o discurso da neutralidade e se permitir uma nova informação estética.

Parafraseando Semog (1997, p. 14) num trecho do seu poema "Visto daqui o além mar", em que diz: 
A palavra não é parte

E, sendo toda,

Firma-se no voo

De ser arte.

Entendendo a AD como essa palavra, propomos: a audiodescrição não é apenas parte isolada da obra e, sendo toda, deve firmar-se no voo de ser arte. Segundo Castro (1998, p. 12), “É preciso desconstruir o conceito metafísico, organicista e ideal de obra de arte. A obra poética apresenta-se como diálogo e o diálogo como obra". Para isso, precisa libertar-se desse discurso enquadrado de ser neutra e de que ser objetiva é antônimo de ser expressiva e poética. Enquanto palavra vivida, a AD é o próprio diálogo. É a própria expressão do real, percepção cooperativa do mundo vivido. Desse lugar, pode ser vivida pela experiência poética. Segundo Castro (1998, p. 13), é na experiência poética que vivenciamos "a verdade e sentido do real como poiesis; concebida como o trazer algo para o desvelado à luz plena e na radiação de uma obra criada". Ou seja, esta se dá pelo diálogo que os sujeitos realizam consigo, com os outros e com as coisas do mundo. Segundo Farias (2013, p. 187),

[...] a experiência poética acontece na experiência do vivido, do homem como ser em situação, vivendo, acontecendo num mundo também nunca totalmente acabado. É uma experiência que ocorre num homem solicitado e aberto a uma infinidade de possibilidades, realizada em trocas. Não há determinismo ou escolha absoluta, o experienciar experiencia o encontro com a physis, com o real.

Segundo Castro (1998, p. 15), "é o concentrar-se na espera do inesperado". Dispor-se a um saber abstrato que anula diferenças, que se oferece como o encontro com o súbito, com o que está por vir, que chega, desencadeia ações, reações, reflexões, conhecimento; ancora e complementa, provocando novos processos, novos compartilhamentos.

Buscando a apropriação dessa experiência poética, apresentamos aqui dois exemplos do que pode ser uma AD neste outro lugar. Primeiro, uma AD de Josélia Neves (ÁVILA; COSTA, 2011):

Fotografia em preto e branco, de Rodrigo Ávila, de 2011. Pernas... são muitas as pernas que baloiçam, longe do chão... perninhas que se amontoam e nascem de corpos jovens que se seguram e aconchegam em colos que mal se contêm. Pés... muitos pés... suspensos em diversas alturas, baloiçando havaianas suas e de outros talvez... grandes demais, pequenas demais, gastas, usadas, por que não novas? Sete irmãs... em escadinha... sobre um parapeito sentadas.

Fotografia 1 - Pernas, pés de crianças sentadas num parapeito

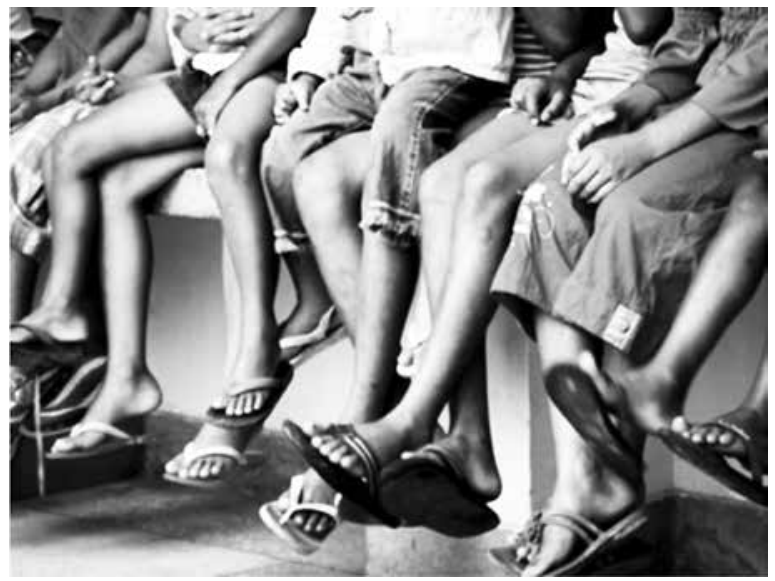

Fonte: Ávila e Costa (2011).

E uma AD de Sandra Rosa (FARIAS; SANTOS, 2015):

Fotografia em preto e branco, de Christian Cravo, 2010. Os feixes de luz enevoados longamente adentram a imensa escuridão, iluminando pouco mais que a cabeça de uma apoucada senhora de costas, um tanto à direita. Ungida em oração, sua introspecta silhueta é desvelada, num simplório vestido escuro e um lenço amarrado atrás da cabeça. Na mão esquerda, uma diminuta vela acesa.

Fotografia 2 - Senhora sob a luz, em meio à escuridão

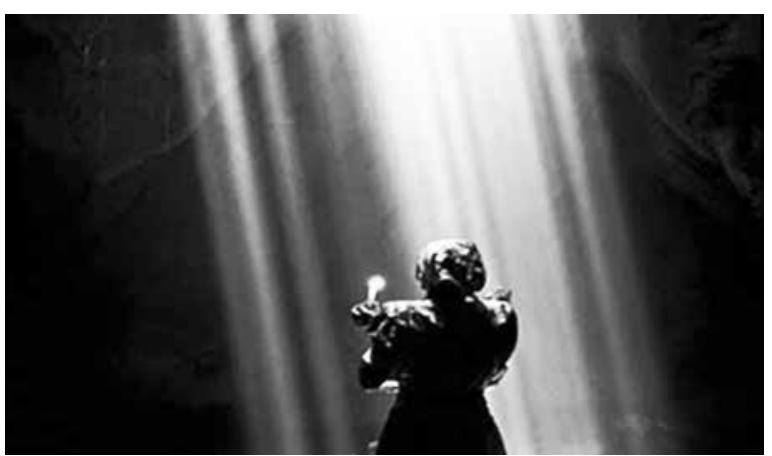

Fonte: Cravo (2010). 
Ao atentar para as duas ADs, do que Farias (2013) propôs, via Britto (2006) para tradução poética, podemos observar os três elementos perceptivelmente. Permite-se, por um lado: "1Identificar as características significativas da imagem e/ou cena de partida" (FARIAS, 2013, p. 189); ou seja, localizar quem são os personagens (pernas que baloiçam longe do chão, perninhas, corpos jovens, mal se contêm, diversas alturas, sete irmãs)/ (apoucada senhora); sua condição social (havaianas suas e de outros talvez, grandes demais, pequenas demais, gastas, usadas, por que não novas?)/ (simplório vestido) e o que estão fazendo (se seguram e aconchegam em colos, sobre um parapeito sentadas)/(Ungida em oração), ou seja, a objetividade da imagem. Também "2atribuir uma prioridade a cada característica, de acordo com maior ou menor grau de contribuição oferecido ao efeito estético total da imagem/cena e ao efeito reflexivo na narrativa como um todo" (FARIAS, 2013, p. 189), ou seja, dentro do que é identificado como prioridade, no primeiro caso, quem é o personagem e como você o identifica, o traduz de forma reflexiva, poética (longe do chão... perninhas que se amontoam e nascem de corpos jovens que se seguram e... mal se contêm). E ainda (suspensos em diversas alturas, baloiçando havaianas suas e de outros talvez... grandes demais, pequenas demais, gastas, usadas, por que não novas?).

Por outro: "3 - recriar as características priorizadas, considerando sua releitura a partir dos elementos da linguagem da própria obra" (FARIAS, 2013, p. 189), como, por exemplo, na segunda AD, em que foi intentado frisar os elementos próprios da fotografia, que se traduzem na relação luz e sombra (Os feixes de luz enevoados que longamente adentram a imensa escuridão... iluminando pouco mais... introspecta silhueta é desvelada, num simplório vestido escuro... diminuta vela acesa). Mais elementos poderiam ser analisados, porém, quisemos ressaltar, também, as escolhas lexicais das audiodescritoras, que promovem um adentrar no universo lírico das imagens, às quais independe sua presença. São as formas expressiva, poética, reflexiva na escolha das palavras que produzem os sentidos, significados e fruição das mesmas.
E é a própria Neves (2011, p. 58) que nos diz:

[...] a escolha lexical numa audiodescrição é de grande importância, pois contribuirá para o tom geral do produto final. A adequação do léxico à temática, ao registo do texto original e ao receptor será, no fundo, a meta a que se deve propor qualquer audiodescrição.

A escolha lexical permite produzir efeitos diferenciados nas imagens, propiciando direcionar significados expressivos a cada contexto específico e à proposta geral da narrativa. Entretanto, cabe ao audiodescritor apreender esta significância e apresentá-la através de "Um léxico variado e sugestivo, conjugado com uma construção frásica clara" (NEVES, 2011, p. 58); entendendo que a subjetividade apreendida deve ser repassada pelo máximo da sua expressividade. Com a $\mathrm{AD}$, não são mais as imagens que compõem a obra (filme, fotografia, teatro, pintura, entre outros), mas a subjetividade apreendida transmutada em expressão (palavras).

E aqui recorremos mais uma vez a Semog (1997, p. 125),

Cavalgar a ferro a palavra

selvagem e permutar o sentido

do corpo pela inércia da alma.

\section{Perder-se num olhar \\ Interno \\ e em cada signo desfazer o detalhe, \\ a minúcia, o significado... \\ deixar aos sábios os limites \\ da angústia e recriar \\ o silêncio com a mesma sabedoria \\ de quem inventa o alimento.}

Entender a AD por esse viés é realizá-la tendo como referência o proposto por Britto (2006) para tradução poética, ou seja, não se deve esperar encontrar o original na sua tradução, pois, em poesia, forma e sentido não acontecem indistintamente. Assim, para a AD, o que se espera encontrar na sua transcriação "é algumas de suas características mais relevantes, num processo de reconstrução do conjunto poético que carreia em si significados, a partir da sua constituição lexical, das rimas, dos sons, de um possível desenho que configura." (FARIAS, 2013, p. 188). De acordo com Campos (1992, p. 181): 
Traduzir a forma, ou seja, o 'modo de intencionalidade' (Art de Meinens) de uma obra - uma forma significante, portanto, intracódigo semiótico - quer dizer, em termos operacionais, de uma pragmática do traduzir, re-correr o percurso configurador da função poética, reconhecendo-o no texto de partida e reinscrevendo-o, enquanto dispositivo de engendramento textual, na língua do tradutor.

A tentativa é transmitir a intimidade incondicional provocada pelos jogos de linguagem que assinalam a obra, mas não transmitir o original, até porque, na AD, a operação é mais complexa. Leva-se em consideração a linguagem da obra de partida (linguagem cinematográfica, da pintura, do desenho, do teatro, da fotografia, entre outras imagens), mas ela é transcriada num signo completamente diferente, o que não permite similaridade, mas sim a palavra esplêndida, na sua máxima completude estética. Nesse sentido, trazemos Adélia Prado (1991), no poema Antes do Nome, para subsidiar nosso lugar de fala:

Não me importa a palavra, esta corriqueira.

Quero é o esplêndido caos de onde emerge a sintaxe, os sítios escuros onde nasce o «de», o «aliás»,

o «o», o «porém» e o «que», esta incompreensível muleta que me apoia.

E, para finalizar, mas não concluir, pois enquanto nascente a $\mathrm{AD}$ ainda tem muito a ser desterritorializada, questionamos com Pirandello (BERNARDO, 2015): “Como podemos nos entender [...] se nas palavras que digo coloco o sentido e o valor das coisas como se encontram dentro de mim; enquanto quem as escuta inevitavelmente as assume com o sentido e o valor que têm para si, do mundo que têm dentro de si?"

\section{Considerações finais}

Compreender a realização da audiodescrição, da relação olhar e palavra, nos remeteu a algumas reflexões. Primeiro como olhamos o mundo. E daí as imagens, as palavras e as pessoas com deficiência visual. E vemos que esse lugar está impregnado da ênfase na objetividade, na neutralidade, na clareza, num mundo produtivo, mas fugaz e, por conta desse olhar, de preconceito. Por ainda serem vistas com o olhar histórico da incapacidade, às pessoas com deficiência visual também são pensadas produções em cima desta limitação (fugaz). E, assim, a audiodescrição, fruto da palavra, igualmente é pensada para que seja realizada por este princípio.

Por outro lado, a palavra, fenômeno ideológico mobilizador da linguagem humana, tem, nas suas muitas possibilidades, a capacidade de tocar a sensibilidade de todos. É com ela, com todas as suas vertentes, que propomos a realização da $\mathrm{AD}$ para produzir e provocar a experiência estética da imagem, ou melhor, da própria palavra.

Se nos dispusermos a um olhar sensível, a admitir as possibilidades, certamente encontraremos, por meio das palavras (oral, escrita, tátil etc.), muitos caminhos significantes para a AD. Realizada deste lugar, a AD será fruto da consciência de que somos pelo reconhecimento das possibilidades, das capacidades, das fruições do outro, bem como as nossas, e pelo respeito à diversidade e às diferenças.

\section{REFERÊNCIAS}

ÁVILA, Rodrigo Viana de; COSTA, Laís de Paula Fiuza. Exposição Identidade pela fotografia: construção e resgate da identidade na Comunidade Novo Aarão Reis. Leiria, PT: Instituto Politécnico de Leiria, 2011.

BADIOU, Alain. Pequeno manual de inestética. Tradução de Marina Appenzeller. São Paulo: Estação Liberdade, 2002.

BAKHTIN, M. Marxismo e filosofia da linguagem. São Paulo: Hucitec, 2002.

BENSE, Max. Pequena estética. São Paulo: Perspectiva, 1971.

BERnARDO, Gustavo. A dúvida de Pirandello. 2005. Disponível em: <http://www.germinaliteratura.com.br/ teatro_outubro05.htm>. Acesso em: 27 ago. 2017.

BÍBLIA. O evangelho segundo São João. Tradução de João Ferreira de Almeida. Versão corrigida e revisada. New Mexico, US: Sociedade Bíblica Trinitariana, 1995. 
BORGES, Jorge Luis. Obras completas de Jorge Luis Borges. v. 3. São Paulo: Globo, 1999.

BUARQUE DE HOLANDA, Aurélio. Novo Dicionário Eletrônico Aurélio versão 5.0. São Paulo: Positivo, 2004.

CAMPOS, Haroldo. Da tradução como criação e como critica. In: Metalinguagem \& outras meta. São Paulo: Perspectiva, 1992. p. 31-48.

CHAUÍ, Marilena. Janela da alma, espelho do mundo. In: NOVAES, Adauto. Et al. O olhar. São Paulo: Companhia das Letras, 1998. p. 31-63.

CRAVO, Christian. Jardins do Éden. São Paulo: Caixa Cultural, 2010.

CRIPPA, A. Mito e cultura. São Paulo: Convívio, 1975.

DINIZ, Débora. O que é deficiência. São Paulo: Brasiliense, 2007.

ECO, Umberto. Lector in Fabula: a cooperação interativa nos textos narrativos. São Paulo: Perspectiva. 1983.

ELIAS, Norbert. Teoria simbólica. Oeiras, PT: Celta Editora, 1994.

FARIAS, Sandra Regina Rosa. Audiodescrição e a poética da linguagem cinematográfica: um estudo de caso do filme Atrás das Nuvens. 2013. 240 f. Tese (Doutorado em Educação) - Faculdade de Educação, Universidade Federal da Bahia, Salvador, 2013.

FARIAS, Sandra R. Rosa; SANTOS, Admilson. A audiodescrição das fotografias de Christian Cravo: representações sociais de pessoas com deficiência visual. 2015.

FLUSSER, Vilém. Filosofia da caixa preta: ensaios para uma futura filosofia da fotografia. São Paulo: Hucitec, 1983.

FRAZER, J. G. La rama dorada. Magia y religión. México: Fondo de Cultura Económica, 1956.

FURTADO, F. Cinema fim-de-século: o dom de iludir. Lumina - Revista da Faculdade de Comunicação Social da Universidade Federal de Juiz de Fora, v. 2, n. 2, p. 125-135, jul./dez. 1999.

GALEANO, Eduardo. As palavras andantes. Porto Alegre: L\&PM, 1994.

JANELA da alma. Direção: João Jardim e Walter Carvalho. São Paulo: Brasil Telecom/Ravina Filmes, 2001. 1 DVD (73 min).

LISPECTOR, Clarice. Amor. In: . Laços de família. Rio de Janeiro: Rocco, 1983. p. 19-29.

MARINHEIRO, Carlos. Ciber dúvidas da Língua Portuguesa. 2010. Disponível em: $<$ http://www.blogdaaudiodescricao.com.br/qual-a-grafia-correta-audiodescricao-audio-descricao>. Acesso em: 29 ago. 2017.

MARTINS, Bruno Sena. E se eu fosse cego? Narrativas silenciadas da deficiência. Porto, PT: Afrontamento, 2006.

MATOS, Olgária. Benjaminianas: cultura capitalista e fetichismo contemporâneo. São Paulo: Editora UNESP, 2010.

MAYER, Flávia Affonso. Imagem como símbolo acústico: a semiótica aplicada à prática da audiodescrição. 2012. 147f. Dissertação (Mestrado em Comunicação Social) - Pontifícia Universidade Católica de Minas Gerais, Belo Horizonte, 2012.

NOVAES, Adauto (Org.). O olhar. São Paulo: Companhia das Letras, 1988.

ORMELEZI, Eliana Maria. Inclusão educacional e escolar da criança cega congênita com problemas na constituição subjetiva e no desenvolvimento global: uma leitura psicanalítica em estudo de caso. 2006. 412f. Tese (Doutorado em Educação) - Universidade de São Paulo, São Paulo, 2006.

PACKER, Jaclyn; KIRCHNER, Corinne. Who's watching? A profile of the blind and visually impaired audience for television and video. New York: American Foundation for the Blind, 1997. Disponível em: <http://www.afb. org >. Acesso em: 16 set. 2010.

PESSOA, Fernando. Livro do desassossego: composto por Bernardo Soares, ajudante de guarda livros na cidade de Lisboa. São Paulo: Companhia das Letras, 2006.

PRADO, Adélia. Poesia reunida. São Paulo: Siciliano, 1991.

SANTOS, Admilson. Representação social de esporte sob a ótica de grupos de pessoas cegas. 2004. Tese (Doutorado em Educação) - Faculdade de Educação da Universidade Federal da Bahia, Salvador, 2004. 
SCHMEIDLER, Emilie; KIRCHNER, Corinne. Adding audio description: does it make a difference? Journal of Visual Impairment \& Blindness, New York, v. 95, n. 4, Apr. 2001. Disponível em: < http://www.periodicos.capes. gov.br>. Acesso em: 16 set. 2010.

SEMOG, Éle. A cor da demanda. Rio de Janeiro: Letra Capital, 1997.

SILVA, Luciene M. Diferenças negadas: o preconceito aos estudantes com deficiência visual. Salvador: Eduneb, 2008.

SILVA, Manoela Cristina Correia Carvalho da. Com os olhos do coração: estudo acerca da audiodescrição de desenhos animados para o público infantil. 2009. 216f. Dissertação (Mestrado em Letras) - Faculdade de Letras da Universidade Federal da Bahia, Salvador, 2009.

VON DER WEID, Olivia. "Visual é só um dos suportes do sonho": práticas e conhecimentos de vidas com cegueira. 2014. 472f. Tese (Doutorado em Antropologia) - Instituto de Filosofia e Ciências Sociais da Universidade Federal do Rio de Janeiro, Rio de Janeiro, 2014.

VYGOTSKY, L. S. A Construção do pensamento e da linguagem. São Paulo: Martins Fontes, 2001.

Recebido: 01/09/2017

Aprovado: 25/10/2017 